Klaster Industri Budaya sebagai Dasar Manuver Politik Korea Selatan

Asinauli Tamba

Departemen Hubungan Internasional, Fakultas Ilmu Sosial dan Ilmu Politik Universitas Diponegoro, Indonesia

asinaulitamba@gmail.com

\section{Reni Windiani}

Departemen Hubungan Internasional, Fakultas Ilmu Sosial dan Ilmu Politik, Universitas Diponegoro, Indonesia

reniwindiani@gmail.com

Satwika Paramasatya

Departemen Hubungan Internasional, Fakultas Ilmu Sosial dan Ilmu Politik,

Universitas Diponegoro, Indonesia

satwikaparamasatya@yahoo.com

\section{SentriS}

SENTRIS ACADEMIC JOURNAL

UNIVERSITAS KATOLIK PARAHYANGAN

BANDUNG

ISSN 0216-5031

VOLUME 2 No. 2

Hal. 192 - 213

https://doi.org/10.26593/sentris.v2i2.5003.192-213 
https://doi.org/10.26593/sentris.v2i2.5003.192-213

\title{
Klaster Industri Budaya sebagai Dasar Manuver Politik Korea Selatan
}

\author{
Asinauli Tamba ${ }^{1}$, Reni Windiani ${ }^{2}$, Satwika Paramasatya ${ }^{3}$ \\ ${ }^{1}$ Departemen Hubungan Internasional, Fakultas Ilmu Sosial dan Ilmu Politik, Universitas Diponegoro, \\ Indonesia, asinaulitamba@gmail.com \\ ${ }^{2}$ Departemen Hubungan Internasional, Fakultas Ilmu Sosial dan Ilmu Politik, Universitas Diponegoro, \\ Indonesia, reniwindiani@gmail.com \\ ${ }^{3}$ Departemen Hubungan Internasional, Fakultas Ilmu Sosial dan Ilmu Politik, Universitas Diponegoro, \\ Indonesia, satwikaparamasatya@yahoo.com
}

\begin{abstract}
Abstrak
Pada Juli tahun 2016, Korea Selatan bersepakat dengan aliansi militernya, Amerika Serikat untuk memasang Terminal High Altitude Area Defense (THAAD) di wilayahnya. Adapun kepentingan Amerika Serikat adalah untuk menyebarkan pengaruh dan menjaga stabilitas kawasan Asia Timur. Sementara, kepentingan Korea Selatan adalah untuk melindungi negaranya dari praktik uji coba nuklir Korea Utara di Semenanjung Korea. Namun pemasangan THAAD ditolak oleh Tiongkok yang menganggap instrumen itu memicu ketegangan di kawasan dan menghambat dominasinya. Dalam menunjukkan ketidaksetujuannya pada kerjasama pertahanan anti-misil THAAD antara Korea Selatan dan Amerika Serikat, Tiongkok memberikan sanksi ekonomi berupa boikot khususnya pada produk-produk industri kebudayaan milik Korea Selatan. Pada Oktober 2017, Korea Selatan menyetujui permintaan Tiongkok untuk mengubah kebijakan THAAD melalui poin-poin yang tercantum dalam Three NOs. Perubahan yang drastis dan signifikan pada politik luar negeri Korea Selatan menjadi hal yang dipertanyakan dalam penelitian ini. Penelitian ini menggunakan teori neorealisme sebagai logika berpikir dan mengemukakan bahwa hallyu atau industri kebudayaan sebagai alasan utama manuver politik yang dipilih Korea Selatan sebagimana boikot Tiongkok sebagai pangsa pasar utama hallyu telah melumpuhkan perekonomian Korea Selatan. Korea Selatan memilih strategi bandwagoning ditengah ancaman demi dapat mempertahankan produksi dan persebaran produk-produk kebudayaan yang tengah menjadi sumber devisa utama nagi negara. Adapun penelitian ini menggunakan metode penelitian kualitatif dengan teknik pengumpulan data yang berupa studi kepustakaan.
\end{abstract}

Kata Kunci: Korea Selatan, Tiongkok, Amerika Serikat, THAAD, Boikot, Industri Budaya, Hallyu.

\begin{abstract}
In July 2016, South Korea agreed with its military alliance, the United States to install Terminal High Altitude Area Defense (THAAD) on its territory. This agreement is the embodiment of the interests of the two countries that were integrated. The United States's interests in spreading influence in the East Asian region and South Korea's interests in protecting the country from North Korea's nuclear test practices on the Korean Peninsula. But the THAAD installation was rejected by China, which considers the instrument as the trigger of tensions in the region and hampering China's dominance. In expressing its disapproval, China imposed economic sanctions by boycott on South Korean-owned cultural industrial products, namely hallyu. In October 2017, South Korea approved China's request to change its THAAD policy through points listed in the Three NOs. The significant changes in South Korean foreign policy are questionable in this study. This study uses the theory of neorealism as a logical thinking and suggests that hallyu as the main reason for the political maneuvering chosen by South Korea as a boycott of China as the main market share of the hallyu has crippled the South Korean economy. South Korea chose a bandwagoning strategy in the midst of threats in order to be able to maintain the production and distribution of cultural products which are currently the main source of foreign exchange for the country. This research uses qualitative research methods with data collection by literature study.
\end{abstract}

Keywords: South Korea, China, United States, THAAD, Boycott, Cultural Industry, Hallyu. 


\section{Pendahuluan}

Selama perang Korea yang terjadi tahun 1950, invasi yang agresif digencarkan Korea Utara dan hampir melumpuhkan pertahanan Korea Selatan (Djelantik, 2015). Sejarah mencatat bahwa Amerika Serikat terlibat dalam perang melalui pengiriman pasukan militer ke semenanjung Korea guna melindungi Korea Selatan (Shambaugh, 2008). Pasca perang, kedua negara membangun aliansi melalui perjanjian Mutual Defense Treaty yang menetapkan Amerika Serikat sebagai aliansi militer sekaligus komando operasi pasukan gabungan diantara Korea Selatan dan Amerika Serikat yang bertanggung jawab untuk merencanakan pembelaan bagi keamanan Korea Selatan. (Gusfianda, 2017). Namun sejak tahun 2006 hingga 2016, keamanan Korea Selatan kembali terancam lewat keagreasifan Korea Utara dalam mengembangkan senjata nuklir di negaranya (Syahrin, 2018). Amerika Serikat kemudian menginisiasi Non-Proliferation Treaty, yaitu suatu perjanjian internasional yang melarang kepemilikan dan pengembangan teknologi nuklir (Charles J. Moxley Jr, 2011). Akan tetapi perjanjian ini gagal membatasi aktivitas nuklir Korea Utara, pasalnya negara ini semakin agresif dalam melangsungkan uji coba nuklir di semenanjung Korea yang menimbulkan security dillema tidak hanya bagi Korea Selatan namun bagi Asia Timur (CTBTO Prepatory Commission, 2017).

Dalam keadaan demikian, sesuai komitmen Amerika Serikat, pada 8 Juli 2016 ditawarkan pemasangan Terminate High Altitude Area Defense (THAAD) pada beberapa wilayah di Korea Selatan. THAAD merupakan sistem pertahanan yang dirancang untuk menangkal dan mendeteksi rudal balistik. Sistem ini tentu menjadi penawaran baik bagi keadaan Korea Selatan, namun pemasangan THAAD justru mendapat penolakan keras dari Tiongkok (Panda, 2017). Tiongkok mengkritik pemasangan sistem THAAD yang dianggap berlebihan apabila hanya untuk kebutuhan pertahanan di semenanjung Korea dan dinilai berpotensi semakin mengganggu stabilitas keamanan kawasan Asia Timur. Korea Selatan berupaya memberikan penjelasan dan menekankan pemasangan THAAD tidak akan berdampak pada Tiongkok ataupun merusak kepentingan keamanan Tiongkok terlebih kawasan, namun hal tersebut tidak cukup efektif membentung kemarahan Tiongkok (Maulana, 2017). Hubungan Korea Selatan dan Tiongkok semakin memanas hingga Tiongkok mengecam Korea Selatan dengan memberikan sanksi ekonomi dan perdagangan berupa boikot terhadap industri budaya milik Korea Selatan. Boikot terhadap industri budaya membuat Korea Selatan mengalami kerentanan pada perekonomian dan menimbulkan economic cost yang tinggi. Pasalnya, industri kebudayaan telah menjadi sumber devisa utama negara dan Tiongkok secara tegas menetapkan sanksi ekonomi ke dalam berbagai aspek dalam indutri kebudayaan. Pada Oktober 2017, Korea Selatan menyetujui permintaan Tiongkok untuk mengubah kebijakan THAAD melalui poinpoin Three NOs. Adapun inti dalam Three NOs adalah boikot Tiongkok diberhentikan hanya apabila Korea Selatan mengembalikan misil milik Amerika Serikat (Axelrod, 1985).

Terdapat beberapa penelitian yang juga mengkaji industri budaya Korea Selatan, boikot Tiongkok, dan keterkaitannya dengan penempatan THAAD milik Amerika Serikat yang kemudian dijadikan sebagai tinjauan pustaka diantaranya: Tinjauan Pustaka pertama adalah skripsi Leo Farhan dengan judul "Kerjasama Militer Korea Selatan - Amerika Serikat dalam Penempatan THAAD (Studi Kasus: Uji Coba Misil Balistik Korea Utara 2013-2017)”. Skripsi ini melihat bahwa fokus kerjasama militer yang dilakukan Korea Selatan dan Amerika Serikat sebagai upaya untuk peningkatan alutsista milik Korea Selatan. Peneliti berpendapat bahwasanya peemerintah Korea Selatan telah menetapkan kebijakan pilihan paling tepat guna melindungi Korea Selatan dari ancaman rudal balistik Korea Utara yakni dengan kesepakatan dan pemasangan THAAD. 
194 Asinauli Tamba, Dr. Dra. Reni Windiani, M.S., Satwika Paramasatya, S.I.P., M.A | Klaster Industri Budaya sebagai Dasar Manuver Politik Korea Selatan

Tinjauan Pustaka kedua adalah skripsi karya Qonita Amalia berjudul "Diplomasi Hallyu terhadap China terkait Kemelut Terminal High Altitude Area Defense di Korea Selatan Tahun 20162017”. Penelitian ini berfokus pada fakta bahwa Tiongkok merupakan pasar yang besar bagi Korea Selatan dalam menyebarkan Hallyunya dan telah menyumbangkan pemasukan bagi kas negara. Untuk itu penulis beragumen bahwa penyebaran Hallyu di pasar Tiongkok di tengah kemelut THAAD berpotensi merusak hubungan interdependent diantara Korea Selatan dan Tiongkok. Sebagaimana Korea Selatan membutuhkan Tiongkok sebagai mitra perdagangan yang besar begitupun Tiongkok yang membutuhkan produk Korea Selatan guna pemenuhan kebutuhan masyarakatnya dan tempat berinvestasi para pengusahanya. Putusan mengenai pemasangan THAAD menimbulkan respon negatif dari negara Tiongkok yang merasa sistem ini cukup meresahkan dan akan membawa kerugian bagi kedua negara. Skripsi ini menggunakan metode kualitatif dan metode pengumpulan data melalui wawancara dan studi kepustakaan.

Tinjauan Pustaka ketiga adalah penelitian yang dilakukan oleh Kim Si-joong yang berjudul "Economic and Trade Relations as an Arena of Korea-China Contention". Penulis menjelaskan bahwa pada dasarnya Tiongkok dengan Korea Selatan telah mempertahankan hubungan ekonomi yang baik sebagaimana terdapat ekspansi yang luar biasa dari adanya perdagangan dan arus investasi antara keduanya. Lebih lagi, hubungan bisnis antara Korea Selatan dan Tiongkok semakin diperlancar dengan adanya Foreign Direct Investment yang disepakati. Hubungan ekonomi bilateral terus meningkat setiap tahunnya dan semakin ketergantungan antara satu sama lain .Namun, kemunculan THAAD menjadi celah bagi keduanya hingga terdapat perselisihan dalam ekonomi dan perdagangan. Kim memprediksi bahwa perselisihan mengenai keamanan, perdagangan, investasi, dan teknologi diidentifikasi sebagai potensi adanya konflik antara Tiongkok dan Korea Selatan di masa depan.

Tinjauan Pustaka keempat adalah jurnal karya Tae Young Kwon yang berjudul "The Effect of THAAD on Korean Consumers and Distributors". Dalam tulisan ini, Kwon mendeskripsikan pengembangan THAAD sebagai ancaman bagi distributor produk-produk Korea Selatan di Tiongkok. Mulai dari produk industri hiburan, sebagaimana Tiongkok telah menjadi pasar utama Korean Wave dan pemblokiran yang dilakukan Tiongkok serta merta memaksa program kebudayaan dan seni Korea Selatan digantikan oleh milik Tiongkok. Pengembangan THAAD juga memberikan dampak pada distributor produk Korean Wave lainnya di Tiongkok yakni pada bidang kosmetik. Sebagai dampak paling parah, THAAD menyebabkan kemuduran pada Lotte Corporation di Tiongkok. Penulis berpendapat bahwa sanksi dan pemblokiran yang dikenakan Tiongkok semakin efektif dengan jiwa nasionalisme yang tinggi dari masyarakat Tiongkok yang serta merta turut melakukan protes dan memboikot Lotte. Tae Young mengambil kesimpulan bahwa pengembangan THAAD di Korea Selatan bukan hanya mempengaruhi sistem pertahanan Korea Selatan, namun juga sistem ekonomi di Korea Selatan kareana persepsi Tiongkok tentang pengembangan THAAD yang membahayakan posisi mereka dan apabila ingin tetap melanjutkan pengembangan THAAD maka Korea Selatan untuk mengurangi ketergantungannya dalam bidang ekonomi dengan pasar Tiongkok, atau sebaliknya melepaskan THAAD demi mempertahankan perekonomian negara (Kwon, 2017).

Berbeda dengan penelitian sebelumnya, penelitian ini berusaha memahami bagaimana Korea Selatan menjalin hubungan bilateral yang erat baik dengan Amerika Serikat sebagai aliansi militer sedari awal maupun Tiongkok sebagai pangsa pasar terbesar bagi persebaran industri kebudayaan Korea Selatan. Kemudian, penelitian ini berangkat dari pertanyaan kunci : "Mengapa Korea Selatan menerapkan manuver politik dengan melepaskan kerjasama keamanan dengan Amerika Serikat dan 
mengikuti kebijakan Tiongkok?". Dan penulis berhipotesa bahwa penyebab Korea Selatan melalukan manuver politik dengan memilih mengikuti kebijakan Tiongkok dan melepaskan kerja sama dengan mitra militernya, Amerika Serikat yaitu karena adanya upaya untuk survive yang dilakukan negara dalam sistem internasional yang anarki. Korea Selatan memilih 'mengekor' kepada ancaman terbesar, lebih lagi dalam kegencarannya untuk mengembangkan industri kebudayaan. Untuk itu, Korea Selatan perlu dekat dengan Tiongkok sebagai pangsa pasar terbesarnya demi semakin meraup keuntungan dalam segi ekonomi dan semakin menimbun kekuatan yang kini dapat dilihat melalui industri kebudayaan.

Metode yang digunakan dalam penelitian ini adalah metode kualitiatif. Penelitian kualitatif merupakan prosedur penelitian dimana data yang didapat, dianalisis dan disimpulkan bukanlah data angka, melainkan data yang sifatnya deskritif, seperti ucapan, tulisan dan perilaku (Furchan, 1992). Penelitian ini menggunakan metode kualitatif didasarkan pada pertimbangan bahwa isu yang diangkat dalam penelitian merupakan suatu fenomena politik sementara metode penelitian kualitatif merupakan metode penelitian yang paling tepat dalam menganalisis sebuah fenomena, peristiwa, aktivitas sosial, sikap, kepercayaan, persepsi dan orang secara individual maupun kelompok (Sukmadinata, 2009). Dalam penelitian dengan metode kualitaif, terdapat dua jenis teknis pengumpulan data yaitu teknik pengumpulan data primer dan teknik pengumpulan data sekunder. Adapun teknik pengumpulan data yang ditetapkan dalam penelitian ini adalah dengan menggunakan teknik pengumpulan data sekunder. Teknik pengumpulan data sekunder berarti teknik yang digunakan dalam memperoleh data bukanlah secara langsung didapat dari sumber asli data, melainkan menggunakan sumber-sumber alternatif yang merujuk pada studi kepustakaan seperti penelitian terdahulu, literatur, review, buku, jurnal, berita internasional, dan web resmi yang berkaitan dengan tema penelitian. Kemudian sebagaimana penelitian ini merumuskan permasalahan yang mempertanyakan alasan dan untuk menjawab pertanyaan "mengapa", maka teknik analisis akan mengacu pada penjelasan fenomena yang berdasarkan sebab-akibat. Oleh karena itu, penelitian ini menggunakan metode kongruen yang lebih berfokus pada variabel independen dan variabel dependen daripada variabel intervensi (Sprinz, 2002). Dengan kata lain, penelitian ini akan berfokus mencari hubungan sebab-akibat diantara kedua variabel tersebut menggunakan data yang dianalisis menggunakan logika berpikir yang dipilih.

\section{Landasan Teori}

Adapun penelitian ini akan menggunakan asumsi-asumsi dasar dari teori neorealisme sebagai dasar berpikir, diantaranya adalah: (1) Sistem internasional adalah anarki dan tidak ada pemerintahan yang absolut atau yang mampu mengatur negara-negara (Waltz, 1979). (2) Ultimate goal atau tujuan utama bagi negara bukanlah power atau kekuasaan melainkan survive atau kelangsungan dan eksistensi negara (Ambarwati dan Subarno Wijatmadja, 2016). (3) Upaya negara untuk survive adalah meningkatkan kapabilitas dan melakukan distribusi kekuasaan (Baldwin, 1993). (4) Dalam kerjasama internasional, alih-alih medapat keuntungan mutlak (absolut gain), neorealisme lebih berorientasi pada keuntungan yang tidak merata (relative gain) (Baldwin, 1993). Selain berbagai asumsi dasar, penelitian ini mengangkan pertimbangan neorealisme terkait seberapa penting kekuasaan bagi negara yang kemudian dibagi atas dua yakni neorealisme defensive dan neorealisme offensive (Robert Jackson and Georg Sørensen, 2013). 
Neorealis defensive memiliki perspektif yang mengabaikan sifat alamiah manusia dan fokus pada dampak yang dihasilkan sistem internasional. Sebagaimana sistem internasional dinilai anarki dan negara dihadapkan dengan sejumlah kekuatan besar, untuk itu negara lemah perlu berupaya dan memilih strategi untuk dapat menghadapinya dan turut menjadi negara kuat (Waltz, 1979). Sementara neorealis offensive menjelaskan bahwa struktur sistemlah yang menentukan bagaimana negara berperilaku dan bagaimana cara negara memandang satu sama lain. Untuk itu, alih-alih hanya berupaya menjadi kuat sama dengan negara lain, neorealisme offensive beranggapan bahwa negara harus berupa meningkankan kekuatannya dan menjadi yang terkuat, karena keseimbangan kekuatan tidak cukup untuk menjamin keamanan (Mearsheimer, 2001). Kemudian untuk menjamini keamanan dan dapat survive dalam sistem internasional yang anarki, neorealisme mengemukakan bahwa terdapat dua strategi yang dapat dipilih negara yakni balancing atau bandwagoning (Rosyidin, 2020).

Balancing adalah strategi yang dipilih negara untuk menjamin keamanan yakni dengan cara saling mengikat dengan negara lain yang memiliki tujuan sama untuk menghadapi ancaman (Walt, 1987). Sedangkan bandwagoning digambarkan sebagai strategi yang ditetapkan negara apabila dalam sistem internasional yang anarki, negara dihadapkan dengan berbagai ancaman yang datang dari kekuatan diluar negaranya. Dalam kondisi ini, alih-alih mengikat dengan negara dengan kekuatan dan kapabilitas sama, negara akan lebih memilih untuk untuk bekerjasama dengan satu negara yang dianggap sebagai source of danger, yaitu satu negara yang dianggap sebagai sebuah ancaman karena mempunyai kekuatan yang besar melebihi kekuatan negara-negara yang bekerjasama dengannya (Waltz, 1979). Dekat dengan sumber ancaman atau kekuatan paling besar tentu membawa dampak bagi negara yang menerapkan strategi bandwagon. Untuk itu, terdapat dua motivasi negara melakukan bandwagoning yaitu, pertama bandwagoning dilakukan sebagai upaya untuk dapat tentram, sebagaimana beraliansi dengan negara yang paling mengancam serta merta akan membuat negara pelaku bandwagoning dapat menghindari ancaman. Kedua, bandwagoning dilakukan sebagai upaya negara untuk dapat meraup keuntungan sebagaimana beraliansi dengan pihak paling kuat dan dominan meampukan aliansinya turut mendapatkan cipratan keuntungan, baik secara ekonomi ataupun citra di kanca internasional (Schweller, 1994).

\section{Pembahasan}

\section{Pergeseran Isu Strategis dari Isu Keamanan Petahanan Menuju Isu Keamanan Ekonomi}

Sebagai negara yang berbatasan langsung dengan Korea Utara, Korea Selatan memutuskan untuk mengembangkan sistem pertahanannya kearah Ballistic Missile Defense (BMD). Selama bertahun-tahun BMD terus dikembangkan seiring berkembangnya misil balistik Korea Utara, akan tetapi perkembangan misil balistik Korea Selatan masih tertinggal jauh dengan misil balistik milik Korea Utara (Kwon, 2017). Selain itu, Korea Selatan juga memiliki perpaduan sistem Patriot dengan baterai PAC-2 yang kemudian ditingkatkan ke PAC-3 yang jauh lebih modern. Pengembangan sistem pertahanan turut diupayakan oleh Korea Selatan lewat memilih mitra paling strategis bagi negaranya, Korea Selatan telah menempatkan Amerika Serikat sebagai komando operasional pertahanan bagi negaranya. Kedua negara secara intens membangun aliansi pertahanan dan hal ini membantu Korea Selatan untuk tetap dapat menjaga keamananya ditengah agresifitas dan kapasitas yang dimiliki oleh Korea Utara. Perkembangan misil balistik Korea Utara yang semakin mengalami perkembangan, 
197 Asinauli Tamba, Dr. Dra. Reni Windiani, M.S., Satwika Paramasatya, S.I.P., M.A | Klaster Industri Budaya sebagai Dasar Manuver Politik Korea Selatan

akhirnya mendorong Korea Selatan untuk turut mengembangkan sistem pertahanan anti-misil Terminal High Altitude Area Defense (THAAD) dengan Amerika Serikat (Elleman, 2016).

Adanya perjanjian yang telah disepakati antara Korea Selatan dan Amerikat Serikat terkait dengan pembangunan THAAD menimbulkan respon negatif dan penolakan keras dari Tiongkok (Ethan Meick \& Nargiza Salidjanova, 2017). Pihak Tiongkok menilai penempatan THAAD di negara Korea Selatan telah merusak hubungan bilateral dalam aspek ekonomi dan perdagangan diantara Korea Selatan dengan Tiongkok. Tiongkok berusaha menyuarakan penolakannya namun pihak Korea Selatan tetap melangsungkan pemasangan THAAD di beberapa titik sesuai ketetapan dengan pihak Amerika Serikat. Sikap Korea Selatan disayangkan Tiongkok dan dianggap menyalahi Tiongkok sebagai salah satu negara dominan di kawasan. Adapun alasan yang diberikan oleh Tiongkok terkait penolakan pemasangan THAAD disemenanjung Korea bersumber dari adanya kekhawatiran Tiongkok terkait keberadaan THAAD yang akan semakin menambah ancaman stabilitas keamanan kawasan sebagaimana dipahami Korea Utara merupakan negara yang agresif dan akan semakin terpancing dengan keberadaan anti-misil balistik di Korea Selatan. Kemudian Tiongkok menyatakan bahwa dengan adanya sistem pertahanan ini, dikhawatirkan sebagai insiasi pihak Amerika Serikat yang dalam hal ini merupakan rival Tiongkok untik dapat melakukan aksi spoinase atau mematamatai aktifitas Tiongkok lewat pemasangan THAAD di wilayah kawasan (Bin, 2017). Selain itu, kemampuan radar yang dimiliki oleh THAAD dapat memicu dan meningkatkan kekhawatiran untuk negara-negara di sekitar kawasan, karena dengan adanya radar tersebut akan mempermudah pihakpihak tertentu mendapatkan informasi kemanan tiap negara (Jethro Mullen and Sol Han, 2017).

Tiongkok akhirnya mengambil langkah-langkah serius untuk menentang penempatan THAAD di Korea Selatan salah satu langkah yang diambil adalah dengan memberikan tekanan dalam ekonomi dan menyuarakan sekaligus mendesak warganya untuk mengekspresikan ketidaksenangan kepada pihak Korea Selatan atas pemasangan THAAD (Putri, 2019). Dalam melakukan aksinya, Tiongkok mengarahkan sanksi boikot kedalam berbagai aspek perdagangan diantara kedua negara, namun terdapat salah satu yang bidang yang dikenai sanksi secara menyeluruh dan intens yakni bidang industri kebudayaan milik Korea Selatan. Sebagaimana Korea Selatan merupakan negara yang aktif dalam memproduksi, mengembangkan, mengenalkan, dan menyebarkan produk kebudayaan melalui ekspor ke berbagai negara, dan dalam hal ini motivasi ekspor didasari oleh motivasi ekonomi yang dimiliki negara. Dalam hallyu, kebudayaan Korea Selatan di industrialisasi hingga dapat dikemas dan disajikan dalam berbagai bentuk dan media hingga mampu dinikmati oleh berbagai kalangan yang bukan hanya dipasarkan di Korea Selatan namun marak di pasar global.

Berikut berbagai bentuk boikot yang dikenakan Tiongkok terhadap produk-produk industri kebudayaan milik Korea Selata, diantara: Pertama adalah drama yang dikenal dengan K-Drama yang mengangkat kisah drama berbagai gender dan mengangkat kebudayaan Korea Selatan dalam penyajiannya. Kedua, musik populer khas Korea Selatan yakni musik bergender pop yang dinyanyikan oleh sekelompok dengan penampilan yang nyentrik dan atian, produk kebudayaan ini dikenal dengan K-Pop. Terdapat tiga perusahaan bidang entertainment yang intens dalam produksi KDrama dan K-Pop dan memasarkannya secara global, diantaranya: "Big Three" yaitu SM Entertainment, YG Entertainment dan JYP Entertainment (Liu, 2007). Selama masa boikot diketahui bahwa saham SM Entertainment jatuh sebesar 8,2 persen menjadi 25.900 Won atau setara dengan 21,9 dollar AS. Selain itu, YG Entertainment juga mengalami penurunan saham sebesar 6,9 persen menjadi 26.300 Won atau setara dengan 23.32 dolar AS dan JYP Entertainment juga mengalami 
penurunan sebesar 2,8 persen menjadi 5.230 Won atau setara dengan 4.64 dollar AS (Sonia Kil, 2017).

Ketiga, produk kebudayaan yang diboikot adalah K-Beauty ataupun kosmetik khas kecantikan Korea Selatan. sebagaimana produjk ini selalu merepresentasikan kecantikan para pesohor dan artis Korea Selatan sehingga kerap disandingkan. Dari adanya kegiatan-kegiatan bidang hiburan ini, maka Korea Selatan tentunya mendapatkan keuntungan yang besar dan menjadi sumber devisa bagi negara yang berdampak untuk peningkatan perekonomian negaranya lewat popularitas dan naiknya industri hiburan Korea Selatan. Tidak hanya mendapatkan devisa lewat bidang hiburan, produk lainnya yang dipasarkan lewat industri kebudayaan turut menjadi pendapatan negara salah satunya lewat ketenaran kosmetik Korea Selatan (Young, 2016). Tiongkok menjadi salah satu negara tujuan ekspor industri hiburan Korea Selatan, dalam hal ini tercatat adanya peminatan tinggi dari massa Tiongkok akan produk-produk hallyu. Keberhasilan hallyu di Tiongkok ditunjukkan dengan adanya ekskalasi ekspor yang mana pada tahun 2016 mencapai 43.189 juta dolar dari 40.312,73 juta dolar AS pada tahun 2015. Selain itu, dalam bidang musik juga mengalami peningkatan yang mana dari bidang ini Korea Selatan berhasil meraup pendapatan sebesar 409 juta dolar AS dan penjualan tayangan langsung acara musik atau konser baik di Korea Selatan maupun di Tiongkok (Ji Eun, 2010). Namun sayangnya, kejayaan industri hiburan Korea Selatan harus mengalami penurunan akibat pemasangan THAAD yang dikecam oleh Tiongkok (Arirang, 2016).

Keempat, bidang pariwisata menjadi bidang yang turut mengalami dampak boikot sebagaimana bidang ini terhubung erat dengan industri kebudayaan milik Korea Selatan. Pasalnyan kebanyakan wisatawan ke Korea Selatan dengan tujuan untuk menikmati pertunjukan kebudayaan seperti konser dan pergelaran kesenian. Tidak hanya itu banyak wisawatan datang untuk mengunjungi tempat-tempat syuting, berbelanja produk kecantikan dan fashion ala Korea Selatan yang dipromosikan lewat konten kebudayaan. Dengan itu, untuk memboikot pariwisata, Tiongkok menerapkan sanksi dengan memberhentikan beberapa maskapai yang memiliki rute ke Korea Selatan (Meick, 2017). Pada tanggal 15 Maret 2017, pemerintah Tiongkok mengumumkan kepada agen wisata yang ada di Beijing terkait adanya larangan penjualan paket liburan dengan destinasi Korea Selatan kemudian larangan ini diberlakukan untuk seluruh agen wisata yang ada di Tiongkok dan diumumkan langsung oleh Administrasi Pariwisata Nasional Tiongkok (Muhaiman, 2017). Kebijakan Tiongkok dalam bidang pariwisata ini tentu memberikan dampak negatif bagi pendapatan Korea Selatan, yang mana menurut data dari Korean Tourism Organization, larangan ini diketahui menekan jumlah turis Tiongkok di Korea Selatan dan mengalami penurunan hingga 66 persen dari total wisatawan mancanegara yang datang ke Korea Selatan. Berdasarkan data terdapat penurunan drastis wisatawan dari tiongkok yang mengunjungi Korea Selatan yang pada tahun 2015 mencapai angka 758.534 orang berkurang menjadi 254.930 orang pada bulan Juni 2016 (Korean Tourism Organization, 2017). Sebagai dampak lainnya, tidak hanya menekan pemasukan pariwisata, penurunan wisatawan Tiongkok ke Korea Selatan juga turut mengurangi pendapatan untuk beberapa department stores ataupun pedagang-pedagang lokal Korea Selatan, sebagaimana diperkirakan wisatawan Tiongkok menghabiskan anggaran dalam berbelanja sebesar 762 dolar AS per orang dalam berbelanja di Korea Selatan (Nielsen, 2017).

Kelima, boikot Tiongkok juga berimbas pada salah satu perusahaan terbesar Tiongkok yayng tersebar di banayk negara yaitu Lotte Grup Corperation. Adapun perusahaan ini mengalami kenaikan dengan membawa bintang-bintang hallyu sebagai media promosi dan selalu dipasarkan dalam 
berbagai produk hallyu seperti drama, film, dan sebbagainya. Hal tersebut yang membawa Lotte pada penjualan tinggi dan persebaran yang meluas. Dalam masa boikot, Lotte Group menjadi fokus kemarahan rakyat Tiongkok karena di duga membantu pihak Korea Selatan dalam penempatan THAAD yang telah mengakibatkan adanya penutupan toko-toko Lotte yang berada di Tiongkok (Jumin Park dan Joyce Lee, 2017). Tercatat sebanyak 115 toko Lotte Mart di Tiongkok berhenti beroperasi, yang mana sebanyak 74 diantaranya ditutup paksa oleh pemerintah Tiongkok dan sebanyak 13 lainnya tutup karena dampak dari lahirnya gerakan menolak Korea yang muncul dari jiwa nasionalisme yang tinggi dari masyarakat Tiongkok yang merasa negara dirugikan dengan keberadaan THAAD di kawasan. Penutupan toko-toko Lotte membawa kerugian yang mencapai trilliunan Won sehingga perekonomian Korea Selatan semakin diambang krisis (Min-hee, 2017).

Dengan melihat berbagai sanksi boikot dan dampaknya dapat dipahami bahwa dalam kemelut masalah pertahanan dan keamanan, Korea Selatan dihadapkan dengan ancaman ekonomi serius dari Tiongkok, sebagaimana Tiongkok menjadi pasar tersebar bagi ekspor produk-produk industri kebudayaan milik Korea Selatan. Sementara dalam periode tahun 2016-2017, pemerintah Korea Selatan tengah secara intens berupaya mengembangkan produksi dan penyebaran produk-produk industri kebudayaannya secara mengglobal. Hal ini tentu menjadi sebuah problematika yang cukup dilematis bagi Korea Selatan, sebagaimana Korea Selatan dihadapkan dalam dua ancaman. Ancaman pertama berupa ancaman dalam segi pertahanan yang tengah dialami lewat keagresifan Korea Utara, adapun ancaman ini juga mempertaruhkan hubungan Korea Selatan dengan aliansi militernya yaitu Amerika Serikat yang memfasilitasi berbagai sistem pertahanan bagi Korea Selatan, secara khusus THAAD. Ancaman kedua yaitu ancaman dalam hal ekonomi yang dialami Korea Selatan pasca pemasangan THAAD dan sanksi boikot yang dikenakan Tiongkok. Adapun ancaman ekonomi telah mambawa berbagai kemerosotan bagi Korea Selatan dalam berbagai sektor ekspor dan perdagangan, pasalnya boikot ini menyerang hallyu secara menyeluruh yang merupakan sumber pendapatan utama negara.

Pada tahun 2017, Korea Selatan menetapkan kebijakan untuk memberhentikan pemasangan pertahanan anti-misil THAAD sesuai keinginan Tiongkok. Sikap ini menunjukkan Korea Selatan lebih memilih untuk fokus pada permasalahan perekonomian dibanding keamanan sekaligus melihat ancaman ekonomi menjadi ancaman paling fatal bagi Korea Selatan. Putusan Korea Selatan turut menggambarkan adanya pergeseran isu strategis di negara yang kemudian mengubah arah kebijakan Korea Selatan. Sebelumnya, permasalahan dan isu utama negara adalah pengembangan kapasitas keamanan dan menjaga stabilitas kawasan terlebih dalam menghadapi agresifitas Korea Utara. Namun kini, Korea Selatan fokus untuk meningkatkan perekonomian lewat hallyu, maka dalam hal ini boikot Tiongkok terhadap produk-produk hallyu menjadi suatu keadaan yang memiliki urgensitas tinggi bagi Korea Selatan (Bin, 2017). Pergeseran isu strategis ini tidak semata-mata menjelaskan bahwa isu keamanan pertahanan militer dikesampingkan Korea Selatan demi isu keamanan ekonomi, sebagimana isu strategis berarti terdapat suatu isu atau kondisi yang harus diperhatikan atau dikedepankan oleh negara karena isu tersebut memiliki dampak yang signifikan bagi negara. Lebih lagi isu tersebut bersifat penting, mendasar, mendesak, dan berjangka panjang. Sesuai dengan persepri neorealisme defensive yang mempercayai bahwa negara-negara berupaya mengumpulkan kekuatan sebagai upaya antisipasi dalam menghadapi ancaman negara lain dan survive jika suatu saat konflik terjadi. Neorealis defensive mengabaikan sifat alamiah manusia dan fokus pada dampak yang dihasilkan sistem internasional. Sebagaimana sistem internasional dinilai anarki dan negara 
dihadapkan dengan sejumlah kekuatan besar, untuk itu negara lemah perlu berupaya dan memilih strategi untuk dapat menghadapinya dan turut menjadi negara kuat. Karena sistem berjalan secara anarkis dan tidak adanya otoritas sentral yang dapat mengatur ataupun mengendalikan keanarkisan diadalam sistem, maka tiap-tiap negara perlu menjadi kuat (Waltz, 1979).

Dalam kata lain, demi menjaga keamanan dan menghindari konflik dalam sistem internasional yang anarki, tiap negara harus memiliki kekuatan yang seimbang sehingga tidak ada yang terancam. Melailui ini dapat dipahami bagaimana Korea Selatan merubah ataupun menggser isu strategis atau fokus negaranya sebagaimana perekonomian negara dan hallyu sebagai pusat industri yang tengah dikembangakan negara sedari awal dalam kondisi terancam melalui boikot Tiongkok. Pergeseran isu ini didasari oleh pertimbangan untuk dapat survive sekaligus dalam memilih strategi dalam kondisi yang terancam. Sebagaimana sistem internasional berjalan secara anarki, maka Korea Selatan akan berupaya meningkatkan kekuatan demi dalam mlawan ancaman dan dalam hal ini hallyu dipandang sebagai kekuatan bagi negara, dengan ini pergeseran isu keamanan pertahanan menuju kemanana ekonomi yang mana sejalan dengan menjadi eksistensi hallyu menjadi antisipasi paling tepat yang dipilih Korea Selatan sebagaimana pemekirin neorealisme defensive terkait upaya survive dan penetapan strategi dan fokus negara. Maka dengan ini, untuk dapat tetap memproduksi dan mengeskpor hallyu, Korea Selatan perlu menggeser isu strategis negara.

\section{Korea Selatan membangun Kepabilitas dan Citra Nasional di Kanca Internasional melalui Hallyu}

Pada tahun 1999, popularitas industri hiburan Korea selatan di tiongkok menghantarkan akademisi pada istilah hallyu. Hallyu berarti adanya ledakan atau pertumbuhan pesat kebudayaan Korea Selatan di kawasan Asia dan secara khusus di Tiongkok. Kebudayaan Korea Selatan kemudian menjadi trend yang membudaya di kalangan muda-mudi di Tiongkok. Mulai dari peminatan kepada produk-produk industri hiburan yang mengangkat kebudayaan seperti film, drama, musik, hingga penggunaan produk-produk yang merepresentasikan Korea Selatan seperti kecantikan ala Korea Selatan. Popularitas hallyu di Korea Selatan juga mampu menggerakkan wisatawan Tiongkok yang memiliki ketertarikan tinggi akan kebudayaan Korea Selatan, untuk berwisata, menghadiri konser musik, mengunjungi berbagai destinasi, hingga berbelanja di Korea Selatan. Persebaran industri kebudayaan Korea Selatan ini bermula di Tiongkok hingga kemudian berkembang ke negara-negara Asia lainnya. Bahkan kini produk-produk industri hiburan dan kebudayaan Korea Selatan dapat ditemui diberbagai kawasan dan telah mendunia. Korea Selatan mengalami perkembangan yang sangat singnifikan dan menjadi pusat produksi budaya terkemuka di Asia (Wibowo, 2013).

Apabila ditelusuri lebih jauh, pada tahun 1980, pemerintah Korea Selatan telah berupaya mengembangan perekonomian negara, namun pemerintah membatasi berbagai aktifitas industri kebudayaan seperti industri perfilman dengan membatasi produksi dan tidak mengizinkan adanya ekspor. Dengan kebijakan tersebut produk-produk kebudayaan hanya menjadi hiburan yang dikonsumsi dalam negeri. Hingga kemudian pada tahun 1987, Korea Selatan dihadapkan dengan kemerosotan perekonomian sebagaimana sistem ekonomi otoritarian yang dianut negara terlalu membatasi cakupan ekonomi, bahkan membatasi ekspresi dan kreatifitas dalam ekonomi. Adapun batasan yang ada dipahami sebagai penyenan stagnannya perekonomian negara. Untuk itu sejak tahun 1987, pemerintah Korea Selatan memberi kebebasan untuk para pekerja seni secara khusus pembuat film untuk berkarya dan memasarkan karya-karyanya. Adapun aktifitas produksi film menggerakkan 
perekonomian ke arah yang lebih demokrasi, meningkatkan pendapatan bagi swasta dan negara. Melalui ini dapat dipahami popularitas industri kebudayaan Korea Selatan tidak terlepas dari intervensi dan pengaruh pemerintah. Sebagaimana sejak tahun 1987, pemerintah berupaya memberi kebebasan bagi para pekerja seni dan memajukan industri kebudayan hingga akhirnya menjadi salah satu sumber pendapatan utama bagi negara (Kim, 2011).

Industri perfilman Korea selatan kemudian menjadi karya yang berkembang dan mampu meraup pasar yang besar secara regional. Tidak berhenti disitu, film-film Korea Selatan mulai dipasarkan dan diekspor ke negara-negara lain dan dinilai mampu bersaing dengan karya-karya film lainnya. Peningkatan ekspor film Korea Selatan terjadi tidak hanya di negara-negara Asia. Dengan ini perfilman Korea Selatan semakin maju dan tentu memberi keuntungan lewat oendapatan dan devisa negara lewat terjualnya film-film Korea Selatan di berbagai negara. Industri kebudayaan tidak berhenti hanya pada perfilman, dengan semakin berkembangnya televisi nasional, pekerja seni mulai memproduksi serial drama yang awalnya hanya ditayangkan di televisi nasional Korea selatan. Namun dengan tingginya minat berbagai negara secara khusus Tiongkok akan penayangan film-film Korea Selatan, drama Korea Selatan turut dinaikkan pada penayangan televisi Nasional Tiongkok. Hal ini yang menjadi cikal bakal ekspor drama Korea ke berbagai negara sebagaimana yang dapat kita temui sejak awal tahun 2000-an hingga kini. Drama Korea menembus pasar-pasar global, bahkan diketahui lebih banyak digemari daripada film, dengan ini ekspor drama korea menemui masa kejayaan dengan rating-rating tinggi hingga berimbas pada kenaikan pendapatan secara signifikan (Parc, 2013).

Kreatifitas pekerja seni tidak berhenti lewat film dan drama, dalam bidang musik, kesenian Korea Selatan turut diinovatif, didesain sedemikian mungkin hingga mampu diminati secara global. Musik Korea Selatan atau yang dikenal dengan k-pop, adapun k-pop menjadi gendre musik kekinian yang mampu mengemas berbagai aliran musik seperti elektro pop, hip-hop, $R \& B$, balada, rock, dan pop yang ditampilkan dengan tarian dan dinyanyikan dalam bahasa Korea dengan keunikan visual yang ditonjolkan. Desain pakaian dan gaya rambut yang terkesan nyentik menjadi ciri khas para musisi Korea Selatan yang kini menjadi trend yang dimati banyak kalangan. Indusuti musik ini banyak menggunakan media televisi sebagai media untuk menyiarkan konser, memasarkan album, menayangkan video klip, menaikkan para musisi sehingga k-pop semakin populer. K-pop menjadi salah satu produk industri kebudayaan yang paling populer setelah drama, tidak hanya diminati negara-negara Asia, k-pop dan bintang-bintangnya semakin mendunia. Berbagai konser digelar tidak hanya di Korea Selatan namun juga digelar secara tour di berbagai benua, meraup keuntungan lewat tiket konser yang terjual habis dan kopian album musik yang di ekspor ke berbagai negara (Chua, 2010).

Industri kebudayaan Korea Selatan merupakan industri yang fokus dalam memproduksi berbagai jenis produk kebudayaan seperti film, drama, musik, kosmetik hingga trend yang dipasarkan. Namun perlu dipahami terdapat keunikan dapal setiap karya yang diproduksi oleh para pekerja seni dalam industri kebudayan Korea Selatan, pasalnya setiap karya yang dihasilkan selalu mengangkan unsur originalitas kebudayaan Korea Selatan atau budaya tradisional Korea Selatan yang dikemas secara modern dan kekinian dalam berbagai produk. Korea Selatan berhasil mamasukkan unsur kenegaraan dalam setiap produk yang diproduksi dan dipasarkan secara mendunia, dan hal ini yang menjadikan industri kebudayaan Korea Selatan terdepan dibandingkan negara lain karena tidak pernah meninggalkan unsur "ke-koreaannya'. Adapun unsur "ke-koreaan" ini dapat ditemui dalam 
setiap film atau drama yang mengangkat kisah historis negara ataupun didesain sedemikian mungkin menyerupai kehidupan masyarakat Korea selatan pada umunya. Nasionalisme yang tinggi dari para pekerja seni turut menjadi elemen penting dalam kelebihan industri kebudayaan Korea Selatan. Popularis kebudayaan yang sangat kental dengan budaya tehional menghantarkan industri kebudayaan Korean Selatan pada fenomena Korean Wave atau gelombang Korea.

Korean Wave menjadi bukti nyata keberhasilan industri kebudayaan Korea Selatan menembus pasar dunia dengan membawa nilai-nilai budaya regional. Dalam fenomena ini diketahui bahwa hampir seluruh negara mengenal, mengkonsumsi bahkan menggemari setiap produk kebudayaan Korea Selatan. Tidak berhenti disitu, kebudayaan Korea Selatan mampu menciptakan trend dikalangan penggemar. Bukan hanya pada film, drama, musik, produk lain seperti kosmetik dan maknaan Korea sangat mendunia hingga diminati secara global. Hal ini merepresentasikan keberhasikan industri kebudayaan dan pemerintah dalam menyebarkan kebudayan hingga menjadi citra baik bagi negara. Para pekerja seni di Korea selatan merepresentasikan dirinya dan karyakaryanya sebagai perwakilan dari Korea selatan untuk itu setiap karya didesain sedemian mungkin mampu menyampaikan pesan yang diharapkan mampu menjadi daya tarik dan representari negara di kanca internasional. Melalui hallyu, Korea Selatan dinilai mampu menyajikan karya seni yang tidak kalah menarik dengan karya-karya yang sedari dulu telah mendunia namun dengan menawarkan sisi "ke-koreaannya". Persebaran hallyu ini kemudian membawa negara kepada berbagai perubahan yang signifikan dan kemajuan. Salah satunya adalah meningkatkan perekonomian negara, hal ini menjadi tujuan utama yang memotivasi negara untuk melakuakan ekspor terkait produk-produk kebudayaan, yaitu motivasi ekonomi. Sehingga melalui semakin maraknya hallyu dipasaran global, maka semakin memampukan negara dalam meningkatkan perekonomian dan menimbun kekayaan lewat devisa. Tidak berhenti disitu, popularitas hallyu turut menambah pemasukan negara lewat pariwisata pasalnya hallyu membuat semakin banyak turis yang ingin melakukan wisata dan menikmati berbagai kebudayaan.

Dampak persebaran hallyu tidak hanya dirasakan melalui sektor perekonomian saja sebagaimana hallyu kini semakin mendunia dan membawa banyak minat dan perhatian negara kepada budaya negara ini,. Untuk itu, hallyu dapat berimbas pada citra nasional yang dimiliki Korea Selatan di kanca internasional. Sebagaimana neoreaisme mengemukakan, untuk tetap dapat survive dan eksis dalam sistem internasional yang anarki, negara perlu meningkatkan kapabilitas secara global sehingga dipandang oleh negara lain. Kapabilitas dalam hal ini menjaelaskan bahwa negara perlu mengerahkann dan memperkuat kemampuan dan kekuatannya untuk dapat membuat negara eksis dan dipandang secara global. Negara yang masyur melalui persebaran kebudayaan menjadi citra nasional yang dibangun oleh Korea Selatan di kanca internasional. Dan dalam hal membangun citra nasional tersebut, industri kebudayaan menjadi kapabilitas utama yang dimiliki Korea Selatan yang menghantarkan negara kepada kekuatan baru yang membuat negara dipandang dan diakui secara mengglobal sebagaimana dalam pembahasan sebelumnya dijelaskan sebagai soft power negara yaitu kekuatan yang dibangun negara untuk menarik negara lain melalui cara-cara non koersif, salah satunya melalui persebaran kebudayaan. Industri kebudayaan Korea Selatan dengan kepopulerannya memiliki peluang untuk dapat menguasai industri hiburan secara global sebagaimana dalam tahuntahun terakhir ini, hallyu semakin mendunia dan telah menjadi citra utama yang dimiliki Korea Selatan. hallyu menjadi kapabilitas yang menunjukkan Korea Selatan mampu survive secara ekononomi dengan citra nasional sebagai negara yang terkemuka lewat kebudayaan, Dengan ini 
memproduksi dan memasarkan industri kebudayaan menjadi upaya yang dilakukan negara, dimana tidak hanya untuk meraup keuntungan secara ekonomi namun untuk dapat membangun kekuatan dan citra nasional di kanca internasional.

\section{Bandwagoning sebagai dasar Perubahan Kebijakan Pemerintah Korea Selatan Periode Tahun 2016-2017}

Dalam upaya meningkatkan pertahanan dan mampu mengimbangi agresifitas Korea Utara secara khusus ditengah dilema keamanan yang dihadapi kawasan, Korea Selatan sepakat untuk memasang THAAD bersama aliansinya, Amerika Serikat. Namun kesepakatan pemasangan sistem pertahanan anti rudal THAAD telah mengganggu hubungan diplomatik sekaligus hubungan ekonomi dan perdagangan diantara Korea Selatan dan Tiongkok (Wall Street Journal, 2017). Tiongkok secara tegas mengemukakan penolakan terhadap kesepakatan terkait THAAD dan menentang Korea Selatan untuk memberi lahan untuk pemasangan sistem pertahanan milik Amerika serikat ini. Tiongkok pun telah mengungkapkan alasan dibalik penolakannya, mulai dari kekhawatiran Tiongkok akan kemampuan radar yang dimiliki THAAD akan keamanan pertahanan yang dimiliki Tiongkok hingga kekhawatiran akan semakin memanasnya dilema keamanan di kawasan dengan keberadaan THAAD, namun tetap tidak merubah putusan Kore Selatan dan bersikeras tetap akan memasang THAAD bersama Amerika serikat dibeberapa titik di negaranya (Banka, 2020). Meskipun Tiongkok telah menunjukkan penolakan, pemerintah Korea Selatan tetap berkomitmen dalam kesepakatan THAAD. Komitmen Korea Selatan terhadap THAAD tidak terlepas dari sikap yang ada pada rezim tersebut, sebagaimana pada 2016, dalam kepemimpinan Moon Jae In, Korea Selatan diketahui sangat dekat dan intens pada hubungan aliansinya dengan Amerika Serikat (Bin, 2017). Korea Selatan melihat Amerika Serikat sebagai aliansi paling potensial yang mampu memberi solusi atas masalah keamanan yang dihadapi Korea Selatan, lebih lagi bantuan pertahanan telah diterima sejak perang Korea dan hingga kini kedua negara fokus menjalin hubungan kerjasama militer dan pertahanan, untuk itu pemerintah Korea Selatan serta merta sepakat pada pemasangan THAAD di wilayahnya tanpa mempertimbangkan dampak dan respon dari sekitarnya, bahkan dari internalnya.

Pasca pemasangan THAAD di langsungkan di beberapa titik, muncul gejolak dan penolakan dari masyarakat Korea Selatan. Terkait isu THAAD, masyarakat Korea Selatan secara khusus yang tinggal tidak jauh dari wilayah pemasangan THAAD, yaitu daerah Seongju ternyata memiliki pandangan yang berbeda dengan pemerintah sebagaimana masyarakat menolak dan melihat sistem pertahanan ini menjadi ancaman bagi masyarakat. Masyarakat di wilayah Seongju menyampaikan kekhawatirannya akan dampak THAAD yang secara langsung dirasakan. Pertama, masyarakat mengkhawatirkan dampak pemasangan yang akan berpotensi mengancam kesehatan masyarakat sekitar lewat radiasi gelombang elektromagnetik yang dihasilkan THAAD, sebagaimana THAAD ditempatkan hanya sejauh 1,5 kilometer dari pemukiman masyarakat. Kedua, masyarakat mengkhawatirkan ketentraman lewat adanya pemasangan THAAD dan penempatan prajurit gabungan Amerika Serikat dan Korea Selatan di sekitarnya yang dinilai sebagai pemicu kriminalitas lewat meningkatnya prostitusi, aksi mabuk-mabukan hingga keanarkisan prajurit yang ditempatkan di Seongju. Penolakan masayarakat Seongju semakin memuncak hingga berakghir pada aksi demonstrasi di Seoul pada 13 Juli 2016, namun tetap tidak merubah sikap pemerintah Korea Selatan pada kesepakatan THAAD bersama Amerika Serikat (Padden, 2016). 
Tidak hanya memicu amarah masyarakat di daerah Seongju, masyarakat pada titik lain wilayah pemasangan THAAD turut bersitegang dengan pemerintah. Masyarakat daerah Soseongri berpendapat bahwa pemasangan THAAD telah merugikan masyarakat karena adanya dampak terhadap lingkungan yang disebabkan oleh radiasi gelombang elektromagnetik yang dihasilkan THAAD. Masyarakat di daerah ini bermata pencaharian lewat petanian dan perkebunan, untuk itu adanya kegagalan hasil panen pasca pemasangan THAAD menjadi pemicu amarah masyarakat. Lebih lagi THAAD dinilai menyalahi karena pemasangannya mengambil wilayah perkebunan milik masyarakat. Dengan ini pada 6 September 2016, masyarakat Soseongri melakukan aksi protes hingga berakhir pada kerusuhan. Namun sikap pemerintah Korea Selatan tetap sama yaitu tetap memihak THAAD dan tidak mempertimbangkan opini masyarakat. Hal ini tampak melalui pengiriman 8.000 polisi ke Soseongri yang diperintahkan oleh Moon Jae in pada saat terjadi aksi protes. Adapun perintah ini ditujukan agar polisi membersihkan jalan sehingga konvoi militer Amerika Serikat yang mengangkut peluncur dan peralatan THAAD dapat berjalan (Al Jazeera English, 2017).

Dalam ketidakstabilkan negara dengan penolakan masyarakat terhadap keberadaam THAAD, pemerintah Korea Selatan tetap komitmen dengan pemasangan THAAD. Sementara kecaman akan keberadaan THAAD telah semakin meluas, tidak hanya datang dari masyarakat di wilayah Soengju dan Sosoengri. Publik Korea Selatan menilai sistem pertahanan anti-misil THAAD bukanlah solusi yang efisien dan efektif karena terlalu banyak resiko yang di hadapkan kepada negara pasca pemasangannya, namun lagi-lagi hal ini tidak mampu merubah pandangan pemerintah Korea Selatan. Hingga kemudian Korea Selatan di kenakan sanksi ekonomi dan perdagangan oleh Tiongkok. Adapun dalam menerapkan sanksi ini, Tiongkok berupaya untuk memberi hukuman dengan menargetkan aspek paling krusial dan berdampak bagi Korea Selatan. Tiongkok memberi sanksi boikot kepada beberapa bidang yang diharapkan memberi efek jera pada Korea Selatan hingga akhirnya mampu merubah sikap dan putusan terkait THAAD (Takruri, 2017).

Terdapat perubahan yang signifikan yang kemudian dipilih oleh pemerintah Korea Selatan terkait THAAD di negaranya. Sanksi ekonomi dan perdagangan yang dikenakan Tiongkok serta merta merubah sikap pemerintah Korea Selatan. Adapun dalam menerapkan sanksi, Tiongkok menerapkan boikot dan pelarangan impor terhadap produk-produk industri kebudayaan milik Korea Selatan seperti film, drama, musik, hingga kosmetik. Tiongkok juga melarang pergelaran kebudayaan di negaranya, membatalkan konser musik Korea Selatan, bahkan menutup akses wisatawan dan agen perjalanan ke Korea Selatan. Adapun boikot yang dikenakan Tiongkok telah menyebabkan kemerosotan dalam perekonomian pasalnya sanksi mambawa hambatan dalam produksi dan penyebaran produk-produk hallyu. Dengan ini Korea Selatan akhirnya memustuskan untuk melepaskan THAAD kepada Amerika Serikat. Adapun proses pengembalian THAAD dilakukan sesuai ketentuan Three Nos yang ditetapkan oleh Tiongkok (Volodzko, 2017). Tidak sedikit masyarakat Korea Selatan mengecam pemerintah atas pemasangan THAAD, jauh sebelum itu, Tiongkok juga telah menunjukkan penolakan saat kesepakatan THAAD di adakan. Namun hal tersebut tidak mampu merubah sikap pemerintah Korea Selatan hingga ada sanksi ekonomi yang dikenakan oleh Tiongkok. Pemerintah Korea Selatan akhirnya menetapkan kebijakan yang kontadiktif dengan komitmen awal yang ditetapkan terkait isu THAAD, dimana diputuskan pemberhentian pemasangan sekaligus pemgembalian THAAD kepada pihak Amerika Serikat. Putusan untuk melepaskan THAAD didasari oleh pemikiran pemerintah yang melihat pemasangan THAAD dianggap melemahkan Korea Selatan sebagaimana boikot Tiongkok 
melumpuhkan pendapatan utama negara yakni lewat ekspor produk kebudayaan dan berdampak pada penurunan devisa negara (Putri, 2019).

Three Nos menjadi kesepakatan yang mengakhiri boikot Tiongkok dan menormalisasi hubungan diantara Korea Selatan dan Tiongkok. Adapun Three Nos merupakan syarat yang ditawarkan oleh Tiongkok kepada Korea Selatan yang dikemukakan pada 11 November 2017 ketika presiden Korea Selatan Moon Jae-in dan presiden Tiongkok Xi Jinping mengadakan pertemuan untuk mengakhiri konflik dan perseteruan diantara kedua negara pasca keputusan Korea Selatan dalam memasang sistem pertahanan THAAD di wilahnya. Kesepakatan Three Nos, atau tiga tidak yang ditetapkan Tiongkok sebagai syarat, meliputi tidak ada penambahan dan pemasangan THAAD di Korea Selatan, tidak ada integrasi atau keikutsertaan Korea Selatan ke dalam sistem pertahanan rudal regional yang dipimpin oleh Amerika Serikat, dan tidak ada aliansi trilateral dengan Amerika Serikat dan Jepang, khusunya dalam bidang pertahanan. Syarat ini secara tidak langsung memaksa Korea Selatan untuk melepaskan dan mengembalikan THAAD kepada Amerika Serikat dan memutus aliansi pertahanan yang telah dibangun, dan sanksi boikot hanya akan diberhentikan apabila Korea Selatan telah mengikuti tiga ketentuan dalam Three Nos (Stangarone, 2019). Three Nos sejatinya menjadi syarat yang berat sebagaimana akan merubah sikap Amerika Serikat, aliansi militer Korea Selatan, terlebih Korea Selatan masih di hadapkan pada dilema keamanan. Namun ancaman kemerosotan perekonomian dinilai sebagai ancaman paling krusial untuk itu syarat yang diberlakukan di terima dan di patuhi oleh Korea Selatan. Efektitas ancaman Tiongkok tentu tidak lepas dari ketepatatn sasaran ancaman yang ditargetkan yakni industri kebudayaan Korea Selatam. Sebagaimana Tiongkok mengancam perekonomian lewat boikot atas industri kebudayaan, yang mana tengah menjadi isu strategis bagi negara sekaligus telah menjadi sumber pendapatan utama Korea Selatan, lebih lagi telah menjadi citra yang dibangun Korea Selatan secara global yakni negara yang sukses lewat persebaran kebudayaannya. Untuk itu kepatuhan akan Three Nos ataupun perubahan sikap dan kebijakan yang drastis dan signifikan mampu ditetapkan Korea Selatan.

Sejatinya, pemerintah Korea Selatan telah menetapkan berbagai agenda dan kebijakan untuk mendukung penuh persebaran hallyu dan terus menyambung keberhasilan negara lewat hallyu. Sejak mulai fokus pada pengembangan industri kebudayaan, pemerintah telah membuat kebijakankebijakan yang mendukung penuh industri kebudayaan. Tahun 1994, Kim Young-sam, presiden Korea Selatan menetapkan kebijakan "Lima Tahun Rencana Pengembangan Budaya" yang memberi dukungan bagi para pekerja seni untuk mengembangkan industri budaya dan pemanfaatan sektor teknologi informasi. Sejak ditetapkannya kebijakan itu, Korea Selatan menjadi negara yang menempatkan industri kebudayaan sebagai komoditas utama yang diekspor demi meningkatkan perekonomian negara. Tidak hanya itu industri kebudayaan menjadi soft power yang dikelola dan dikembangkan dalam upaya diplomasi sekaligus membangun citra negara. Popularitas hallyu yang mampu menembus pasar global, membuat Korea Selatan merasa perlu memaksimalkan kepabilitas dan kapasitas negara lewat sektor kebudayaan yang mana diupayakan mampu menjadi strategi untuk menimbun kekuatan negara baik dalam politik, ekonomi, hingga keamanan. Ide dan pemikiran ini terus diusung dan ditanamkan dalam pemerintahan. Pada tahun 2001, dalam rezim Kim Dae-Jung, pemerintah turut menekankan pentingnya membangun industri kebudayaan yang dianggap sebagai mesin yang mampu menumbuhkan perekonomian yang membawa Korea Selatan dikenal secara mendunia. Dengan ini menjaga keberlangsungan dan keberhasilan hallyu seakan menjadi peran yang di amanahkan pada setiap rezim. Sehingga ketika Tiongkok memboikot industri kebudayaan, dengan 
itu Korea Selatan serta merta akan terancam, lebih lagi karena Tiongkok merupakan pangsa pasar utama bagi bagi produk-produk kebudayaan milik Korea Selatan.

Korea Selatan melakukan manuver politik atau perubahan kebijakan secara drartis dan cepat yang mencakup perubahan isu strategis sekaligus pergeseran aliansi yang ditetapkan pemerintah Korea Selatan demi menjaga eksistensi industri budaya yang menjadi sumber perekonomian utama negara. Manuver politik ini dapat dipahami melalui sikap Korea Selatan sebagaimana sejak perang Kore, bahkan sejak semakin dihadapkan dengan keagresifitasan Korea Utara akan kepemilikan nuklir, Korea Selatan menetapkan isu pertahanan dan militer sebagai isu strategis negara, yang berusaha digenapi bahkan dengan menetapkan negara lain yakni Amerika Serikat sebagai mitra komando pertahanan bagi negaranya. Hubungan yang dibangun Korea Selatan dan Amerika Serikat sejatinya bukanlah sebatas bilateral namun kedua negara tengah menjadi aliansi sejak bantuan Amerika Serikat dalam perang Korea dan berbagai kerjasama pertahanan yang dicanangkan kedua negara secara intens. Akan tetapi, boikot Tiongkok terhadap industri kebudayaan mampu menggeser dan mengubah Korea Selatan dalam memandang aliansinya, lebih lagi memutus kerjasama pertahanan yang telah ditetapkan demi menjaga stabilitas Korea Selatan ditengah kepemilikan nuklir Korea Utara. Dengan serta merta, Korea Selatan mengikuti arahan Tiongkok untuk melepas THAAD, manjadi cerminan bagaimana Korea Selatan mampu melepas isu dilema keamanan yang tengah dihadapi negara, lebih lagi melepas hubungan dengan aliansi sedari awal demi mempertahankan industri kebudayaan.

Adapun sikap yang dinamis dan sangat drastis tersebut diputuskan dengan pertimbangan bahwasanya pemerintah mengedepankan keberlangsungan popularitas industri kebudayaan Korea Selatan yang dipandang akan menjadi kekuatan bagi negara dan tengah menjadi potensi utama yang akan dikembangkan negara secara khusus dalam aspek ekonomi. Dalam sistem internasional yang anarki, Korea Selatan dihadapi dengan dua ancaman berupa ancaman kehilangan mitra keamanan sekaligus ancaman semakin tidak stabilnya kawasan dan disisi lain negara dihadapi oleh ancaman kehilangan pangsa pasar utama bagi persebaran industri kebudayaan, adapun Korea Selatan memilih untuk lebih dekat kepada sumber ancaman yang paling berbahaya bagi negaranya yakni Tiongkok yang mengancam Korea Selatan akan kehilangan popularitas industri kebudayaan, lebih lagi dalam masa itu, periode tahun 2016-2017 menjadi timing yang menentukan popularitas industri kebudayaan Korea Selatan hingga kini. Pasca melepaskan kerjasamana THAAD sesuai ketentuan Three Nos, Korea Selatan menormalisasi hubungan dengan Tiongkok. Keseriusan Korea Selatan dalam menempatkan industri kebudayaan sebagai prioritas pengembangan dan sumber pendapatan negara tidak berhenti hanya pada kebijakan politik melepaskan THAAD, pemerintah semakin serius dan intens dalam pengembangan hallyu yang dioptimalkan lewat berbagai kebijakan yang ditetapkan pemerintah. Bukan hanya lewat kebijakan berbagai lembaga resmi pemerintahan juga didirikan yang secara khusus mengemban tugas dan tanggung jawab untuk melangsungkan persebaran dan menjaga kontiunitas persebaran dan popularitas hallyu secara global. Adapun industri kebudayaan sejatinya telah memiligi badan yang meaungi yakni Kementrian Budaya, olahraga, dan Pariwisata Korea Selatan, namun keagresifan pemerintah ditunjukkan dengan pembentukkan lembaga-lembaga lainnya, seperti Korea Creative Content Agency (KOCCA), Korea Foundation for International Cutural Exchange (KOFICE), dan Korean Tourism Organization (KTO) (VOI.id, 2020).

KOCCA adalah lembaga di bawah naungan Kementrian Budaya, olahraga, dan Pariwisata Korea Selatan yang mengkoordinasikan, memperkenalkan, dan memaasarkan industri kebudayaan Korea Selatan secara regional maupun global. Lembaga ini disebut sebagai lembaga kreatif karena 
berfokus untuk menangani bidang ekonomi kreatif yang tengah dikembangkan Korea Selatan yaitu industri hallyu. Lembaga yang berkantor pusat di Naju atau yang dikenal sebagai "kota budaya dan seni" ini menjadi wadah bagi berbagai produk dan konten kebudayaan Korea Selatan, seperti musik, game, komik, penyiaran, animasi, fashion, dan konten-konten lainnya. Lembaga ini mengintegrasikan lima organisasi bedar dalam bidang indutri budaya Korea Selatan, diantaranya: the Korea Culture \& Content Agency atau organisasi yang menjadi wadah bagi masyarakat Korea Selatan yang memiliki ide dalam mengembangkan ekonomi kreatif, the Cel Academy atau organisasi pusat pelatihan penciptaan konten budaya Korea Selatan, the Cel Venture Complex atau organisasi yang khusus menaungi startup atau industri digital yang baru merintis di Korea Selatan, the Korean Broadcasting Institute atau organisasi yang menjadi wadah pelatihan bagi media penyiaran Korea Selatan dan the Korea Game Agency atau organisasi yang fokus dalam pengembangan bisnis game dan digital. Selain mengembangkan berbqagai ide kreatif dan bisnis yang baru merintis, lembaga ini menjadi wadah yang memberi pelayanan pengembangan mutu dan kualitas sumber daya manusia sehingga masyarakat semakin kreatif dalam berbisnis dan berkebudayaan (Korea Creative Content Agency, 2017).

KOFICE merupakan lembaga di dibawah naungan pemerintahan yang mengemban tugas untuk mempromosikan industri kebudayaan Korea Selatan melalui program-program akademik dan pertukaran budaya, selain itu lembaga ini berupaya untuk membangun pemahaman bersama tentang kebudayaan Korea Selatan dengan komunitas internasional. Lembaga ini memuat berbagai program untuk melancarakian misi menyebarkan industri kebudayaan Korea Selatan. Program pertama adalah Enhancement of Korean Studies and Language Overseas, merupakan program yang memberi dukungan pada berbagai penelitian dan studi kajian tentang Korea Selatan terkait bahasa maupun budaya di berbagai universitas di dunia. Tidak hanya itu, program ini turut memberi dukungan untuk penelitian Korea Selatan di luar negeri. Program kedua adalah Forum and Research, merupakan program yang menetapkan pertemuan dan dan membentuk forum komunikasi diantara pihak-pihak non-pemerintah, pemerhati kebudayaan untuk mendiskusikan berbagai inovasi pada industri kebudayaan, Program ketiga adalah Cultural Exchange, merupakan program yang aktif dalam mendukung kegiatan promosi kebudayaan melalui berbagai program kebudayaan, seperti pendirian museum, galeri serta penyelenggaraan program-program kebudayaan lainnya. Keempat, Publications and Material, merupakan program yang memiliki kewenangan dalam mempublikasikan berbagai literatur dan buku dalam bahasa asing, program ini juga mendukung kegiatan produksi konten-konten multimedia kebudayaan Korea Selatan. Kelima, The Korea Foundation Cultural Center, merupakan program yang memiliki tujuan pembangunan dan pemeliharaan gedung-gedung yang didedikasikan untuk mengenalkan kebudayaan Korea Selatan (Indah Chartika Sari dan Ahmad Jamaan, 2019).

KTO merupakan lembaga pemerintahan yang bergerak secara khusus dalam bidang pariwisata yang memiliki tanggung jawab untuk memperomosikan periwisata Korea Selatan ke mancanegara. Sebagaimana dipahami, industri kebudayaan menjadi hal yang berkaitan erat dengan periwisata di Korea Selatan. Pasalnya berbagai produk-produk industri kebudayaan berhasil menarik wisawatan dan membuat pariwisata negara mengalami eskalasi. Penggemar k-pop masuk ke Korea Selatan dengan tujuan menyaksikan konser dan pertujukan musik secara langsung, penggemar berbagai judul drama mengunjungi Korea Selatan untuk dapat secara langsung melihat tempat-tempat syuting drama yang akhirnya menjadi destinasi wisata di Korea Selatan. Tidak berhenti disitu, kosmetik dan fashion yang diangkat oleh produk-produk kebudayaan menarik wisatan untuk datang 
menikmati berbagai produk dan berbelanja ke Korea Selata, untuk itu lembaga KTO dan semakin memperjelas keterikatan keterikatan diantara industri kebudayaan dan periwisata yang mana keduanya menjadi sumber devisa bagi negara. Berbagai program dan kinerja ditetapkan lembaga ini dalam upaya mempromosikan pariwisata dan kebudayaan Korea Selatan, seperti menggunakan bintang-bintang hallyu yang banyak di gemari secara global sebagai duta pariwisata Koresa Selatan, menggelar acara Korean Travel Fair (KTF) dengan pihak-pihak swasta untuk semakin mempromosikan Korea Selatan sebagai destinasi budaya, menggelar festival kebudayaan Korea Selatan di berbagai negara, dan berbagai program lainnya. Lembaga ini juga turut membuat berbagai program pariwisata kebudayaan yang diupayakan ramah bagi setiap pihak, seperti program wisata ramah Muslim yang digelar karena memahami pasar kebudayaan datang dari berbagai negara dan kebudayaan (Korea Tourism Organization, 2019).

Pemerintah Korea Selatan telah menetapkan berbagai kebijakan demi dapat menyebarkan dan menjaga eksistensi hallyu di kanca Internasional. Adapun kebijakan yang dipilih Korea Selatan untuk melapaskan THAAD dan menormalisasi hubungan Tiongkok juga dipengaruhi oleh kepentingan Korea Selatan dalam menjamin kontinuitas hallyu di pasar global, sebagaimana hallyu telah menjadi kekuatan negara baik secara ekonomi maupun politik. Hallyu menmbentuk citra Korea Selatan sebagai negara yang "eksis" melalui industri kebudayaan. Dapat dipahami melalui berbagai kebijakan yang ditetapkan pemerintah Korea Selatan, secara khusus kebijakan dalam melepaskan THAAD diakibatkan pertimbangan negarada dalam mengedepankan industri kebudayaan sehingga tetap dapat survive dalam sistem internasional yang anarki.

\section{KESIMPULAN}

Isu keamanan di semenanjung Korea menjadi isu strategis yang dihadapi Korea Selatan sejak perang Korea bahkan samapai tahun-tahun terakhir ini karena keagresifan Korea Utara dalam kepemilikan dan uji coba muklir. Amerika Serikat hadir menjadi aliansi militer bagi Korea Selatan yang sekaligus telah menjadi mitra komando pertahanan Korea Selatan pasca bantuan pertahanan dalam perang Korea dan berbagai kerjasama militer yang secara intens ditetapkan kedua negara, salah satunya perjanjian pertahanan bersama atau Mutual Security Agreement yang diinisiasi pada tahun 1953. Pada tahun 2016, negara-negara di kawasa Asia Timur, terlebih Korea Selatan kembali dihadapkan pada dilema keamanan karena uji coba nuklir yang secara intens dilangsungkan oleh Korea Utara di semenanjung Korea. Untuk itu, sebagai aliansi militer bagi Korea Selatan dan juga sebagai negara yang ingin menjamin stabilitas keamanan di kawasan Asia Timur, Amerika Serikat mengambil peran dengan mengirimkan sistem pertahanan anti-misil balistik, THAAD yang dipercaya dapat mendeteksi, meradar, dan melumpuhkan nuklir kepada Korea Selatan. Sejatinya, pemasangan THAAD di Korea Selatan menjadi topik yang menuai banyak kontroversi di Korea Selatan. Dimulai dari adanya publik yang menolak pemasangan THAAD dengan pertimbangan lingkungan dan kekhawatiran akan dampak pemasangan THAAD di sekitar pemukiman masyarakat. Namun dipahami pemerintah Korea Selatan secara khusus dalam rezim Moon Jae In menanggapi opini publik dengan tetap melangsungkan pemansangan THAAD karena dianggap menjadi solusi paling tepat ditengah ancaman uji coba nuklir yang semakin intens dilangsungkan oleh Korea Utara. Satu-satunya yang 
dapat merubah komitmen pemerintah Korea Selatan terkait THAAD adalah kemerosotan negara pasca boikot yang dikenakan Tiongkok secara khusus terhadap industri kebudayaan milik Korea Selatan.

Bagi Korea Selatan, penyebaran industri kebudayaan telah menjadi isu strategis negara sebagaimana industri kebudayaan telah menjadi fokus utama negara dalam pengembangan perekonomian, lebih lagi sebagai kekuatan baru yang telah diupayakan negara. Kebijakan luar negeri suatu negara acapkali berkaitan dengan aliansi, sebagaimana negara memiliki mitra paling potensial bagi negaranya. Dalam kasus ini Amerika Serikat telah menjadi aliansi bagi Korea Selatan, keberadaan Korea Selatan sekarang tidak terlepas dari upaya aliansinya yang membantu bahkan sejak sejarah perang Korea. Namun fenomena manuver politik yang dipilih Korea Selatan periode tahun 2016-2017 menjelaskan bahagimana aliansi tidak menjadi penentu utama, sebagaimana Korea Selatan mampu mengaubah kebijakan secara drastis dan serta merta meninggalkan aliansinya sedari awal.

Bagi Korea Selatan sesuai dengan ide utama Neorealisme, upaya untuk survive menjadi hal utama yang diperjuangkan negara ditengah sistem internasional yang anarki. Adapun dalam periode tahun 2016-2017, Korea Selatan dihadapkan dalam dua ancaman berupa kehilangan aliansi militer Amerika Serikat, ditengah ketidakstabilan kondisi kawasan atau kehilangan pangsa pasar terbesar Tiongkok, ditengah pengembangan dan persebaran hallyu. Dalam kondisi demikian, sebagaimana perilaku bandwagoning menjelaskan, Korea Selatan memilih untuk dekat kepada sumber ancaman paling berbahaya bagi negaranya. Bagi Korea Selatan, adanya hambatan bagi persebaran hallyu dan boikot Tiongkok jauh lebih riskan dibanding dilema keamanan yang tengah ada. Hal ini didasarkan pada isu strategis yang ditetapkan pemerintah dan menjadi fokus utama dan penentu arah kebijakan negara.

\section{Daftar Pustaka}

Adorno, M. H. T., 1944. The Curtural Industry. Edinburgh: Edinburgh University Press.

Al Jazeera English, 2017. South Korea Farmers Fear Toxic Effects of Anti-Missile Defence System. [Online]

Available at: https://www.yout5qE1S4FNYf4ube.com/watch?v=

[Accessed 2 April 2021].

Ambarwati dan Subarno Wijatmadja, 2016. Pengantar ilmu hubungan internasional. 1st ed. Malang: Intrans Publishing.

Axelrod, R., 1985. Achieving Cooperation under Anarchy: Strategies and Institutions. World Politics, 38(1), pp. 226-254.

Baldwin, D. A., 1993. Neorealism and Neoliberalism : The Contemporary Debate. 2nd ed. Columbia : Columbia University Press.

Banka, N., 2020. Explained: Why China is opposing THAAD defence systems in South Korea. [Online]

Available at: https://indianexpress.com/article/explained/thaad-missile-defence-system-south-koreaus-china-6434536/

[Accessed 28 April 2021]. 
210 Asinauli Tamba, Dr. Dra. Reni Windiani, M.S., Satwika Paramasatya, S.I.P., M.A | Klaster Industri Budaya sebagai Dasar Manuver Politik Korea Selatan

Bin, L., 2017. The Security Dilemma and THAAD Deployment in the ROK. [Online]

Available at: https://www.chinausfocus.com/foreign-policy/the-security-dilemma-and-thaaddeployment-in-the-rok

[Accessed 21 Maret 2021].

Charles J. Moxley Jr, J. B. a. J. G., 2011. Nuclear Weapons and Compliance with International Humanitarian Law and the Nuclear Non-Proliferation Treaty. Fordham International Law Journal, XXXIV(1), p. 681.

Chua, B., 2010. Korean Pop Culture. Malaysian Journal of Media Studies, XXII(1), p. 16.

CTBTO Prepatory Commission, 2017. GENERAL OVERVIEW OF THE EFFECTS OF NUCLEAR TESTING. [Online]

Available at: https://www.ctbto.org/nuclear-testing/the-effects-of-nuclear-testing/general-overviewof-theeffects-of-nuclear-testing/

[Accessed 22 September 2020].

Djelantik, S., 2015. Asia Pasifik : Konflik, Kerja Sama, dan Relasi Antarkawasan. In: Jakarta: Yayasan Pustaka Obor Indonesia, p. 39.

Elleman, M., 2016. North Korea-Iran Missile Cooperation. [Online]

Available at:

https://www.38north.org/2016/09/melleman092216/?_cf_chl_captcha_tk_=0db3b1505f8e8358c1f3 ab24d3dcf27de55eb0d2-1618567414-0-ASfUoS80m6OixHKXHv95GEKOZdlYE iBmAyb4C6wYyhuoke64jKW7iMbL4qMtKx8InxWe7Xew9tUyQW112AN9bbPhZ5UwO_5sxH4EMT7xUqT W2bwR-IqyYDLSySJKqMk1c

[Accessed 13 Maret 2021].

Ethan Meick \& Nargiza Salidjanova, 2017. China's Response to U.S..-South Korean Missile Defense System Deployment and Implications. [Online]

Available at:

https://www.uscc.gov/sites/default/files/Research/Report_China\%27s\%20Response\%20to\%20THAA D\%20Deployment\%20and\%20its\%20Implications.pdf

[Accessed 21 Maret 2021].

Furchan, A., 1992. Pengantar Penelitian Dalam Pendidikan. 1st ed. Surabaya: Usaha Nasional.

Gusfianda, B., 2017. Aliansi Militer Dan Keamanan Amerika Serikat-Korea Selatan Pasca Perang Dingin Dan Pengaruhnya Di Kawasan Asia Timur. Global Insight Journal, 2(1).

Harrell, P., 2018. CHINA'S USE OF COERCIVE ECONOMIC MEASURES. [Online] Available at: https://s3.amazonaws.com/files.cnas.org/documents/China_Use_FINAL1.pdf?mtime $=20180604161240$

[Accessed 25 November 2020].

Indah Chartika Sari dan Ahmad Jamaan, 2019. HALLYU SEBAGAI FENOMENA TRANSNASIONAL. [Online]

Available at: https://media.neliti.com/media/publications/31286-ID-hallyu-sebagai-fenomenatransnasional.pdf

[Accessed 2 Mei 2021].

International Institute for Strategic Studies, 2017. The Militery Balance. Routledge, p. 244.

Jethro Mullen and Sol Han, 2017. One company is bearing the brunt of China's anger over U.S. missile system. [Online] 
211 Asinauli Tamba, Dr. Dra. Reni Windiani, M.S., Satwika Paramasatya, S.I.P., M.A | Klaster Industri Budaya sebagai Dasar Manuver Politik Korea Selatan

Available at: https://money.cnn.com/2017/03/07/news/china-lotte-thaad-south-koreatensions/index.html

[Accessed 9 February 2021].

Ji-Hyoung, S., 2016. EXO's Nanjing Concert Put on Hold. [Online]

Available at: https://www.thejakartapost.com/life/2016/12/07/exos-nanjing-concert-put-on-hold.html [Accessed 22 November 2020].

Ju-min Park dan Joyce Lee, 2017. South Korea's Lotte Approves Land Swap for Missile Defence: Ministry. [Online]

Available at: https://www.reuters.com/article/us-southkorea-usa-thaad-lotte-idUSKBN1660P6 [Accessed 30 March 2021].

Jun, H., 2017. Hallyu at a Crossroads: The Clash of Korea's Soft Power Success and China's Hard Power Threat in Light of Terminal High Altitude Area Defense (THAAD) System Deployment. Asian International Studies Review, June, XVIII(1), pp. 153-168.

Kim, M., 2011. The Role of Government in Cultural Industry : Some Observations From Korea's Experience. Keio Communicatiion Review, I(33), pp. 163-182.

Korea Creative Content Agency, 2017. KOCCA Introduction. [Online]

Available at: https://www.kocca.kr/en/main.do

[Accessed 1 Mei 2021].

Korea Tourism Organization, 2019. KTO Overview. [Online]

Available at: https://kto.visitkorea.or.kr/eng.kto

[Accessed 1 Mei 2021].

Kwon, T. K. W., 2017. The Effect of THAAD on Korean Consumers and Distributors. Journal of Marketing Thought, 3(4), pp. 49-65.

Liu, 2007. The Rising Korean Wave among Chinese Youth. CSP 104 Academic Writing Skills. CSP 104 Academic Writing Skills, I(1), p. 112.

Maulana, V., 2017. China Tegaskan Tetap Tolak Penempatan THAAD di Korsel, s.1.: SINDONEWS.

Mearsheimer, J., 2001. The Tragedy of Great Power Politics. 2nd ed. United States: W.W Norton and Company.

Meick, E., 2017. China's Response to U.S.-South Korean Missile Defense System Deployment and Implications. U.S.-China Economic and Security Review Commission, I(1), pp. 4-7.

Min-hee, J., 2017. Lotte Faces 500 Billion Won Losses in China over THAAD Retaliation. [Online] Available at: http://www.businesskorea.co.kr/news/articleView.html?idxno=18007

[Accessed 25 March 2021].

Ministry of Foreign Affairs of PRC, 2016. Foreign Ministry Spokesperson Hua Chunying's Remarks on China Lodging Representations with ROK and US over Start of Discussions on Deploying THAAD in $R O K$. [Online]

Available at:

https://www.fmprc.gov.cn/mfa_eng/xwfw_665399/s2510_665401/2535_665405/t1339507.shtml

[Accessed 8 February 2021].

Muhaiman, 2017. Data Uji Coba Nuklir Korut dari Masa ke Masa. [Online]

Available at: https://international.sindonews.com/berita/1236457/40/data-uji-coba-nuklir-korut-dari- 
212 Asinauli Tamba, Dr. Dra. Reni Windiani, M.S., Satwika Paramasatya, S.I.P., M.A | Klaster Industri Budaya sebagai Dasar Manuver Politik Korea Selatan

masa-ke-masa

[Accessed 22 Maret 2021].

Padden, B., 2016. THAAD Radiation Fears Spark South Korean Protests. [Online]

Available at: https://www.voanews.com/east-asia-pacific/thaad-radiation-fears-spark-south-koreanprotests

[Accessed 25 April 2021].

Panda, A., 2017. Chinese Defense Ministry: Opposition to THAAD 'Will Definitely Not Stay On Word Only. [Online]

Available at: https://thediplomat.com/2017/03/chinese-defense-ministry-opposition-to-thaad-willdefinitely-not-stay-on-words-only/

[Accessed 8 August 2020].

Parc, J., 2013. Korean Dramas and Films: Key Factors for Their International Competitiveness. Asian Journal of Social Science, XXXXI(2).

Putri, A. S., 2019. Pengaruh Terminal High Altitude Area Defense (THAAD) Terhadap Hubungan Dagang Korea Selatan-Tiongkok. Journal of Chemical Information and Modeling, 6(1), pp. 1-15.

Putri, A. W., 2016. Cina Memboikot K-Pop Gara-Gara Urusan Nuklir. [Online] Available at: https://tirto.id/cina-memboikot-k-pop-gara-gara-urusan-nuklir-b5Wv [Accessed 20 March 2021].

Robert Jackson and Georg Sørensen, 2013. Introduction to International Relations: Theories and Approaches. 5th ed. Oxford: Oxford University Press.

Rosyidin, M., 2020. Teori Hubungan Internasional : Dari Perspektif Klasik Samapai Non-Barat. 2nd ed. Yogyakarta: Raja Grafindo Persada.

Schweller, R. L., 1994. Bandwagoning for Profit: Bringing the Revisionist State Back In. International Security, XIX(1), pp. 72-107.

Shambaugh, D., 2008. International Relations of Asia (Asian in World Politics). Maryland: Rowman and Littlefield Publisher.

Stangarone, T., 2019. Did South Korea's Three Noes Matter? Not So Much. [Online]

Available at: https://thediplomat.com/2019/10/did-south-koreas-three-noes-matter-not-so-much/ [Accessed 2 Mei 2021].

Sukmadinata, N. S., 2009. Metode Penelitian Pendidikan. 1st ed. Bandung: Remaja Rosdakarya.

Swaine, M., 2017. China Views on South Korea's Deployment of THAAD. China Leadership Monitor, I(52), pp. 3-4.

Syahrin, M. N. A., 2018. KEAMANAN ASIA TIMUR : REALITAS, KOMPLEKSITAS DAN RIVALITAS. In: Depok: Komojoyo Press, p. 21.

Takruri, D., 2017. Soseong-ri: Hub of South Korea's Anti-THAAD Movement. [Online] Available at: https://www.aljazeera.com/features/2017/9/22/soseong-ri-hub-of-south-koreas-antithaad-movement

[Accessed 3 April 2021].

Tempo.co, 2015. Cina-Korea Selatan Teken Perjanjian Perdagangan Bebas. [Online]

Available at: https://bisnis.tempo.co/read/671391/cina-korea-selatan-teken-perjanjian-perdagangan- 
213 Asinauli Tamba, Dr. Dra. Reni Windiani, M.S., Satwika Paramasatya, S.I.P., M.A | Klaster Industri Budaya sebagai Dasar Manuver Politik Korea Selatan

bebas

[Accessed 24 April 2021].

VOI.id, 2020. Mendalami Invasi Drama Korea: Dukungan Pemerintah dan Strategi Pelaku Industri. [Online]

Available at: https://voi.id/tulisan-seri/6203/mendalami-invasi-drama-korea-dukungan-pemerintahdan-strategi-pelaku-industri

[Accessed 1 Mei 2021].

Volodzko, D. J., 2017. China wins its war against South Korea's US THAAD missile shield - without firing a shot. [Online]

Available at: https://www.scmp.com/week-asia/geopolitics/article/2120452/china-wins-its-waragainst-south-koreas-us-thaad-missile

[Accessed 1 Mei 2021].

Wall Street Journal, 2017. Why China Opposes Thaad in South Korea. [Online]

Available at: https://www.youtube.com/watch?v=TNUdUzrKp0k

[Accessed 1 Mei 2021].

Walt, S. M., 1987. Origins of Alliances. 1st ed. Ithaca: Cornell University Press.

Waltz, N. K., 1979. Theory of International Politics. New York: McGraw Hill.

Wibowo, W., 2013. K-Drama, Industri Kreatif Berbasis Budaya Populer. In: Budaya Hallyu Korea. Yogyakarta: The International Association of Korean Studies in Indonesia, pp. 19-28.

Young, Y. J., 2016. China Bands Import of 19 Korean Cosmeti. [Online]

Available at: https://www.scmp.com/news/asia/est-asia/article/2061152/china-bansimport19koreancosmetic

[Accessed 23 March 2021]. 